\title{
The Endocannabinoid 2-Arachidonoylglycerol Is Responsible for the Slow Self-Inhibition in Neocortical Interneurons
}

\author{
Silvia Marinelli, ${ }^{1}$ Simone Pacioni, ${ }^{1}$ Tiziana Bisogno, ${ }^{2}$ Vincenzo Di Marzo, ${ }^{2}$ David A. Prince, ${ }^{3}$ John R. Huguenard, ${ }^{3}$ and \\ Alberto Bacci ${ }^{1}$ \\ ${ }^{1}$ European Brain Research Institute, 00143 Rome, Italy, ${ }^{2}$ Endocannabinoid Research Group, Istituto di Chimica Biomolecolare-Consiglio Nazionale delle \\ Ricerche, 80078 Pozzuoli, Napoli, Italy, and ${ }^{3}$ Department of Neurology and Neurological Sciences, Stanford University School of Medicine, Stanford, \\ California 94305
}

In the CNS, endocannabinoids are identified mainly as two endogenous lipids: anandamide, the ethanolamide of arachidonic acid, and 2-arachidonoylglycerol (2-AG). Endocannabinoids are known to inhibit transmitter release from presynaptic terminals; however we have recently demonstrated that they are also involved in slow self-inhibition (SSI) of layer V low-threshold spiking (LTS) interneurons in rat somatosensory cortex. SSI is induced by repetitive firing in LTS cells, which can express either cholecystokinin or somatostatin. SSI is triggered by an endocannabinoid-dependent activation of a prolonged somatodendritic $\mathrm{K}^{+}$conductance and associated hyperpolarization in the same cell. The synthesis of both endocannabinoids is dependent on elevated $\left[\mathrm{Ca}^{2+}\right]_{\mathrm{i}}$ such as occurs during sustained neuronal activity. To establish whether 2-AG mediates autocrine LTS-SSI, we blocked its biosynthesis from phospholipase C (PLC) and diacylglycerol lipases (DAGLs). Current-clamp recordings from LTS interneurons in acute neocortical slices showed that inclusion of DAGL inhibitors in the whole-cell pipette prevented the long-lasting hyperpolarization triggered by LTS cell repetitive firing. Similarly, extracellular applications of a PLC inhibitor prevented SSI in LTS interneurons. Moreover, metabotropic glutamate receptor-dependent activation of PLC produced a long-lasting hyperpolarization which was prevented by the CB1 antagonist AM251, as well as by PLC and DAGL inhibitors. The loss of SSI in the presence of intracellular DAGL blockers confirms that endocannabinoid production occurs in the same interneuron undergoing the persistent hyperpolarization. Since DAGLs produce no endocannabinoid other than 2-AG, these results identify this compound as the autocrine mediator responsible for the postsynaptic slow self-inhibition of neocortical LTS interneurons.

Key words: neocortex; endocannabinoids; interneurons; 2-AG; inhibition; SSI

\section{Introduction}

Endocannabinoids are the endogenous ligands of the cannabinoid receptor CB1 and CB2. These receptors are the target of $\Delta^{9}$-tetrahydrocannabinol, the active principle of the recreational drug marijuana, well known for its psychoactive and analgesic effects (Freund et al., 2003; Iversen, 2003). Activation of the cannabinoid system typically leads to disruption of psychomotor behavior, short-term memory impairment, intoxication, and stimulation of appetite (Iversen, 2003; Di Marzo and Matias, 2005). At the cellular level, activation of CB1 receptors activates potassium channels (Deadwyler et al., 1995; Mackie et al., 1995)

\footnotetext{
Received 0ct. 22, 2008; accepted 0ct. 27, 2008.

This work was supported by the Giovanni Armenise-Harvard Foundation Career Development Award (A.B.); European Commission Marie Curie International Reintegration Grant (A.B.); National Alliance for Research on Schizophrenia and Depression Young Investigator Award (A.B.); Ministero dell'Università e della Ricerca (Fondo per gli Investimenti della Ricerca di Base) and Italian Institute of Technology (A.B.); National Institutes of Health Grant NS39579 from the National Institute of Neurological Disorders and Stroke (D.A.P., J.R.H.); and the Morris and Pimley research funds (D.A.P.). We thank Drs. Raj Razdan (Organix), and Billy Martin (Department of Pharmacology and Toxicology, Virginia Commonwealth University) for the gift of 0-3841.

Correspondence should be addressed to Dr. Alberto Bacci, European Brain Research Institute, Via del Fosso di Fiorano 64, 00143 Roma, Italy. E-mail: a.bacci@ebri.it.

DOI:10.1523/JNEUROSCI.0847-08.2008

Copyright $\odot 2008$ Society for Neuroscience ～0270-6474/08/2813532-10\$15.00/0
}

and inhibits calcium channel function (Mackie and Hille, 1992; Kreitzer and Regehr, 2001). Since CB1 receptors are highly expressed in presynaptic terminals, CB1-mediated effects on calcium channels can result in a reduced release of either GABA or glutamate (Hájos et al., 2000; Kreitzer and Regehr, 2001; OhnoShosaku et al., 2001; Wilson et al., 2001; Freund et al., 2003).

We have recently found that, in layer $\mathrm{V}$ of rat neocortex, a subtype of GABAergic interneurons, classified as low-threshold spiking (LTS), undergoes a prominent and long-lasting hyperpolarization following their own repetitive firing. This slow selfinhibition (SSI) is due to the postsynaptic activation of a G-protein-coupled inward rectifier potassium (GIRK) conductance triggered by an activity-dependent autocrine action of endocannabinoids (Bacci et al., 2004).

Endogenous cannabinoids are identified mainly in two endogenous lipids: the ethanolamide of arachidonic acid, anandamide (Devane et al., 1992; Mechoulam et al., 1994), and 2-arachidonoylglycerol (2-AG) (Mechoulam et al., 1995; Sugiura et al., 1995). The "on demand" biosynthesis of anandamide and 2-AG is strongly dependent on rises of intracellular $\mathrm{Ca}^{2+}$ concentration (Di Marzo et al., 1994; Cadas et al., 1996; Bisogno et al., 1997; Cadas et al., 1997; Sasaki and Chang, 1997; Stella et al., 
1997; Stella and Piomelli, 2001), such as occur during sustained neuronal activity. Anandamide and 2-AG are synthesized through different biochemical pathways, both using phospholipids as precursors. Anandamide is synthesized via hydrolysis of the phospholipid precursor $\mathrm{N}$-arachidonoyl phosphatidylethanolamine via potentially alternative pathways (Di Marzo et al., 1994; Sugiura et al., 1996a,b; Liu et al., 2008; Simon and Cravatt, 2008). Two possible pathways involving phospholipase C (PLC), or phosphatidic acid hydrolase are believed to lead to the synthesis of 2-AG (Freund et al., 2003; Piomelli, 2003; Di Marzo et al., 2005). Diacylglycerols (DAGs), a major source of $2-A G$ for these pathways, are always converted into the endocannabinoid by diacylglycerol lipases (DAGLs) (Bisogno et al., 1997, 1999; Stella et al., 1997), and are in turn produced via either PLC-dependent or -independent pathways. The last step of 2-AG biosynthesis is catalyzed by a specific enzyme, $s n-1-D A G$ lipase, which is present in two isoforms in neurons (DAGL $\alpha$ and DAGL $\beta$ ). The expression of $s n$-1-DAG lipase- $\alpha$ in postsynaptic cells of adult rodents is correlated with 2-AG biosynthesis (Bisogno et al., 2003; Yoshida et al., 2006). DAGL substrates can be produced by PLC $\beta$, which cleaves membrane phosphatidylinositol 4,5-bisphosphate $\left(\mathrm{PIP}_{2}\right)$ into $\mathrm{IP}_{3}$ and DAG (Freund et al., 2003; Piomelli, 2003; Bisogno et al., 2005). In neurons, PLC $\beta$ can be activated by group I metabotropic glutamate receptors (mGluRs). Indeed, endocannabinoiddependent modulation of both short- and long-term synaptic transmission relies on mGluR activation in several brain areas (Varma et al., 2001; Brown et al., 2003; Freund et al., 2003; Piomelli, 2003; Jung et al., 2005; Maejima et al., 2005; Chevaleyre et al., 2006; Jung et al., 2007). Although the active players in the synthetic pathways of both anandamide and 2-AG are known, specific pharmacological agents that can be used to block the biosynthesis of endocannabinoids are lacking. Recently, specific inhibitors for the DAGL have been synthesized (Bisogno et al., 2006). Here we show that SSI can be robustly induced in LTS interneurons that express the neuropeptide somatostatin (SST), extending our previous findings demonstrating SSI expression in CCK-containing LTS cells. Blocking the last step in 2-AG production prevented SSI. Moreover, PLC blockade prevented SSI, whereas PLC activation by a mGluR agonist mimicked SSI in LTS interneurons. Together these results identify $2-\mathrm{AG}$ as the endogenous cannabinoid responsible for the induction of this phenomenon.

\section{Materials and Methods}

In vitro slice preparation and electrophysiology. Sprague Dawley rats aged postnatal day 13 (P13)-P21 were deeply anesthetized with pentobarbital $(50 \mathrm{mg} / \mathrm{kg})$ and decapitated, and their brains were removed and immersed in cold "cutting" solution $\left(4^{\circ} \mathrm{C}\right)$ containing (in mM): 234 sucrose, 11 glucose, $24 \mathrm{NaHCO}_{3}, 2.5 \mathrm{KCl}, 1.25 \mathrm{NaH}_{2} \mathrm{PO}_{4}, 10 \mathrm{MgSO}_{4}$, and 0.5 $\mathrm{CaCl}_{2}$, gassed with $95 \% \mathrm{O}_{2} / 5 \% \mathrm{CO}_{2}$. Coronal slices $(300 \mu \mathrm{m})$ were cut from somatosensory cortex (parietal area 1) with a vibratome and then incubated in oxygenated artificial CSF (ACSF) containing (in mM): 126 $\mathrm{NaCl}, 26 \mathrm{NaHCO}_{3}, 2.5 \mathrm{KCl}, 1.25 \mathrm{NaH}_{2} \mathrm{PO}_{4}, 2 \mathrm{MgSO}_{4}, 2 \mathrm{CaCl}_{2}$, and 10 glucose; $\mathrm{pH} 7.4$, initially at $32^{\circ} \mathrm{C}$ for $1 \mathrm{~h}$, and subsequently at room temperature, before being transferred to the recording chamber and maintained at $32^{\circ} \mathrm{C}$. Recordings were obtained from visually identified interneurons in layer $\mathrm{V}$, easily distinguished from pyramidal neurons by the lack of a large emerging apical dendrite. LTS cells were identified by previously described electrophysiological properties (Bacci et al., 2003b, 2004).

Experiments were performed in the whole-cell configuration of the patch-clamp technique. Electrodes (tip resistance $=2-3 \mathrm{M} \Omega$, and 5-7 $\mathrm{M} \Omega$ for experiments involving biocytin fills) were filled with an intracellular solution containing (in mM): $70 \mathrm{~K}$-gluconate, $70 \mathrm{KCl}, 2 \mathrm{NaCl}, 10$ HEPES, 10 EGTA, $2 \mathrm{MgCl}_{2}$; $\mathrm{pH}$ adjusted to 7.3 with $\mathrm{KOH} ; 290 \mathrm{mOsm}$. In some experiments $\mathrm{K}$-gluconate and $\mathrm{KCl}$ were 130 and $10 \mathrm{~mm}$ respectively. Drugs were delivered using a local perfusion system composed of multiple fine tubes ending in a common outlet tube, positioned in proximity $(\sim 250 \mu \mathrm{M})$ to the recorded neuron. Experiments were performed in the presence of the ionotropic glutamate receptor blockers 6,7dinitroquinoxaline-2,3, dione (DNQX, $10 \mu \mathrm{M}$ ) and DL-2-amino-5phosphonovaleric acid (DL-APV, $100 \mu \mathrm{M}$ ) in the bath and local perfusate. In some experiments the $\mathrm{GABA}_{\mathrm{A}}$ receptor blocker gabazine $(10 \mu \mathrm{M})$ was included in the perfusate. Tetrahydrolipstatin (THL) was obtained from the Di Marzo laboratory, whereas O-3841 was a kind gift from Raj Razdan's laboratory (Organix). AM-251, CHPG, U73122, tetrodotoxin, DNQX, gabazine, and DL-APV were from Tocris Bioscience. U-73343 was from Sigma.

Signals were amplified using a Multiclamp 700B patch-clamp amplifier (Molecular Devices), sampled at $20 \mathrm{kHz}$, and filtered at $10 \mathrm{kHz}$, unless otherwise noted. A Digidata 1320 digitizer and PClamp9 (Molecular Devices) were used for data acquisition and analysis. Membrane conductance was measured from responses to small current injections $(-15$ to $-30 \mathrm{pA}, 250 \mathrm{~ms}, 0.2 \mathrm{~Hz})$. SSI-inducing stimuli consisted of 10 trains of either 10 or $50 \mathrm{~Hz}$ APs (60 APs/train), evoked every 20 s. Results are presented as means \pm SEM. Unless otherwise noted, paired Student's $t$ test was used to compare control data with those obtained in the same neurons after drug applications or 5-8 min following SSI-inducing stimuli. Differences were considered significant if $p<0.05$.

Immunocytochemistry. Biocytin (0.1-0.05\%, Sigma) was included in the internal solution to fill neurons during electrophysiological recordings. Slices were subsequently fixed overnight in $4 \%$ paraformaldehyde in phosphate buffer $(\mathrm{PB}, \mathrm{pH} 7.4)$ at $4^{\circ} \mathrm{C}$, cryoprotected in $30 \%$ sucrose in $0.1 \mathrm{M}$ phosphate buffer and sectioned (40 $\mu \mathrm{m}$ thickness) with a cryostat (Leica). Sections were blocked in PB + BSA 10\%+ Triton X-100 0.3\% for $2 \mathrm{~h}$, and incubated overnight with anti-CCK (5 mg/ml diluted 1:1000 in $\mathrm{PB}+0.3 \%$ Triton X-100 and $0.1 \%$ normal donkey serum) antibody. For CCK immunostaining we used a monoclonal antibody raised against CCK/Gastrin (No. 28.2 MoAb) that was kindly provided by Dr G. Ohning at the CURE/Digestive Diseases Research Center, Antibody/RIA Core, University of California, Los Angeles. Sections were rinsed twice in $\mathrm{PB}$ and incubated for $3.5 \mathrm{~h}$ in secondary antibodies (donkey anti mouseCy2 1:100, Molecular Probes), diluted in PB $+0.3 \%$ Triton X-100 and $0.1 \%$ normal donkey serum. Sections were rinsed in $\mathrm{PB}$ and incubated $1 \mathrm{~h}$ in Cy3-conjugated streptavidin (Jackson ImmunoResearch, diluted 1:250). For SST-immunostaining, slices were incubated with an anti-SST antibody (1:250; rabbit anti somatostatin T-4103, Peninsula Laboratories) overnight at $4{ }^{\circ} \mathrm{C}$ with $0.3 \%$ Triton $\mathrm{X}-100$ and $0.1 \%$ normal donkey serum in PB. Slices were rinsed in $\mathrm{PB}$ and incubated $3.5 \mathrm{~h}$ in $\mathrm{PB}$ with $0.3 \%$ Triton X-100, secondary Cy2-conjugated anti-rabbit antibody (1:100, Jackson ImmunoResearch), and Cy3-conjugated streptavidin (1:250, Jackson ImmunoResearch). Fluorescent biocytin-filled neurons and CCK or SST immunoreactivity were then observed with a laser confocal microscope (Leica SP5) and images were acquired.

\section{Results}

\section{Somatostatin-positive LTS interneurons express CB1-mediated SSI}

We obtained whole-cell recordings from interneurons in rat neocortical slices. Interneurons were identified morphologically using infrared videomicroscopy as cells with round bipolar or multipolar cell bodies, lacking a clear apical dendrite. Firing behavior in current clamp was characterized in response to square DC current injections, as previously published (Bacci et al., 2003a,b, 2004). In layer V, we found two major neuronal subtypes that could be characterized as GABAergic interneurons by their firing behaviors: (1) cells that responded to depolarizing steps with abrupt fast spiking (FS), with little or no adaptation and the absence of a rebound burst following a hyperpolarizing step [these interneurons are typically morphologically identified as basket or chandelier cells (Kawaguchi and Kubota, 1997, 1998)]; (2) low-threshold spiking (LTS) cells, which generated an action 

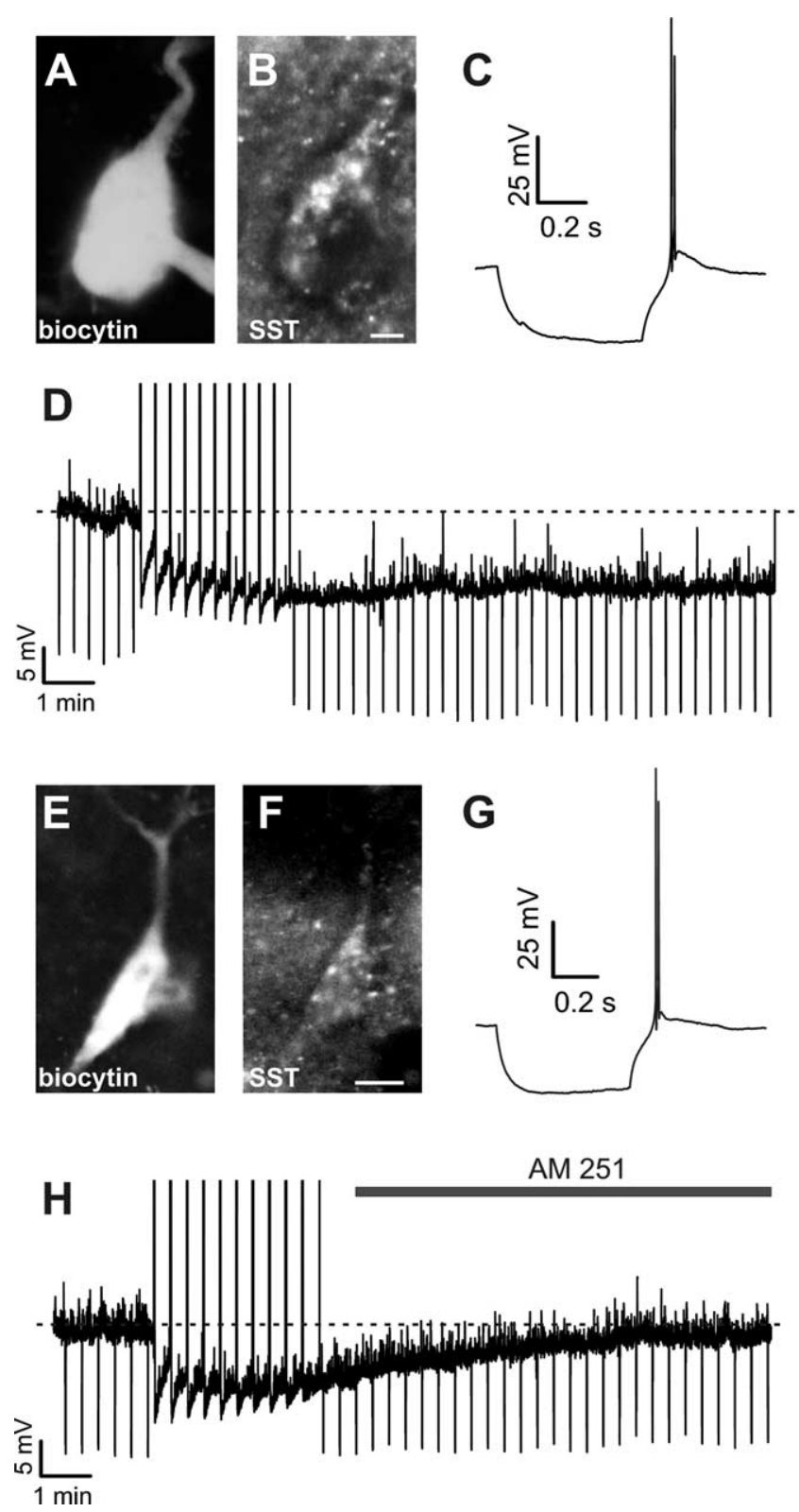

Figure 1. CB1-dependent SSI in neocortical LTS interneurons expressing the neuropeptide somatostatin. $\boldsymbol{A}$, Example of a biocytin filled interneuron, processed with Cy3-conjugated streptavidin. $\boldsymbol{B}$, The same slice was counterstained using an antibody against the neuropeptide SST, indicating that the same cell was SST-positive. C, Firing properties of the cell of A-B, showing the typical rebound burst overriding a low-threshold spike (LTS) in response to a hyperpolarizing current step $(-70 \mathrm{pA}) \cdot V_{\mathrm{m}}$ was $-62 \mathrm{mV}$. D , The same cell as in $A-C$ showed a persistent hyperpolarization (slow self-inhibition, SSI) in response to 10 trains of action potentials at $50 \mathrm{~Hz}$ (intertrain intervals: $20 \mathrm{~s}$ ). Negative deflections represent responses to negative current injections $(-30 \mathrm{pA})$, showing reduced $g_{\mathrm{m}}$ associated to the hyperpolarization. $\boldsymbol{E}$, Example of another biocytin filled interneuron processed with Cy3-conjugated streptavidin. $\boldsymbol{F}$, The cell of $\boldsymbol{E}$ showed SST-immunoreactivity. $\boldsymbol{G}$, The cell of $\boldsymbol{E}$ and $\boldsymbol{F}$ showed typical rebound LTS firing behavior in response to hyperpolarizing current injection as in $\boldsymbol{C} . V_{m}:-58 \mathrm{mV}$. $\boldsymbol{H}$, Cell of E-G responded to $S S I$-inducing stimuli with a hyperpolarization, which was reversed by extracellular application of the CB1R antagonist AM 251 (3 $\mu \mathrm{m}$ ). Scale bars: $\boldsymbol{A}, \boldsymbol{B}, 2.5 \mu \mathrm{m} ; \boldsymbol{E}, \boldsymbol{F}, 5 \mu \mathrm{m}$.

potential or a rebound burst of spikes riding on a depolarizing hump following a hyperpolarizing current injection (Fig. $1 C, G$ ) and a relatively adapting firing behavior in response to depolarizing steps (Bacci et al., 2003a,b, 2004). Although LTS cells might include several morphologically identified interneuron subtypes (Kawaguchi and Kubota, 1997, 1998), we previously found that neocortical layer V LTS cells we recorded consistently expressed the neuropeptide CCK (Bacci et al., 2004), which is known to be coexpressed with CB1 receptors in the neocortex and hippocampus (Katona et al., 1999; Marsicano and Lutz, 1999; Freund et al., 2003; Bodor et al., 2005). However, the vast majority of deeplayer cortical LTS interneurons are known to express the neuropeptide somatostatin (SST) (Cauli et al., 1997; Kawaguchi and Kondo, 2002; Goldberg et al., 2004; Ma et al., 2006) and little or no overlap between CCK- and SST-containing interneurons has been shown (Kawaguchi and Kondo, 2002; Uematsu et al., 2008). Interestingly, $\mathrm{CB} 1 \mathrm{mRNA}$ expression has been detected in a vast majority of SST- and calbindin $\mathrm{D}_{28 \mathrm{~K}}$-positive cells ( $>60 \%$; Hill et al., 2007), in line with previous evidence showing CB1 mRNA expression in a significant percentage of calbindin $\mathrm{D}_{28 \mathrm{~K}}$-positive interneurons (Marsicano and Lutz, 1999). Notably, calbindin $\mathrm{D}_{28 \mathrm{~K}}$-positive cortical interneurons frequently coexpress somatostatin (Kawaguchi and Kubota, 1997; Hill et al., 2007). In the present study we extended our previous preliminary immunohistochemical results (Bacci et al., 2004) and tested whether SSTexpressing LTS interneurons could generate slow self-inhibition (SSI). We filled neurons with biocytin and counter-stained them with antibodies against SST or CCK $(n=56)$ (Fig. $1 B, F$; supplemental Fig. 2, available at www.jneurosci.org as supplemental material). We found that LTS interneurons can express either SST $(n=36)$ (Fig. $1 B, F)$ or CCK $(n=8)$ (supplemental Fig. 2, available at www.jneurosci.org as supplemental material). In these experiments, we might have underestimated the total number of SST- or CCK-positive cells, as immunoreactivity was lost in many experiments, likely due to the dialysis of LTS neuron cytoplasm by whole-cell pipettes. This was indicated by the appearance of biocytin-positive neurons devoid of reaction product $(n=21$, data not shown), and by a higher incidence of immunopositive neurons when whole-cell recordings lasted $<1 \mathrm{~min}$. However, we cannot exclude the possibility that neurons lacking expression of SST and CCK represent another subtype of LTS cells. In a previous publication, we reported that 7 LTS cells filled with biocytin contained CCK (Bacci et al., 2004), whereas in the current results 36 of 56 of LTS cells were SST positive and only 8 of 56 contained CCK. We have no explanation for this difference, although the relatively small number of immunoreacted cells in the earlier experiments may have provided an inadequate sample.

When LTS interneurons were stimulated by directly evoking 10 trains of 60 action potentials at either 10 or $50 \mathrm{~Hz}, 78 \%(n=$ 47) responded to these cycles of activity with a prominent and long-lasting hyperpolarization (Figs. $1 D, 2 A, 3 A$ ), as previously described (Bacci et al., 2004). SSI was associated with an increase in membrane conductance measured as a reduced response to a hyperpolarizing current injection delivered every 5-20 s throughout the experiment (Figs. $1 D, H, 2 B, 3 B$ ). Membrane conductance was not different when the $V_{\mathrm{m}}$ was reset to baseline levels with DC current injection during the slow SSI-induced hyperpolarization $\left(2.64 \pm 0.4 \mathrm{nS}\right.$ vs $2.16 \pm 0.6$, post-SSI $g_{\mathrm{m}}$ vs post-SSI $g_{\mathrm{m}}$ with DC current injection; $p>0.2$; pre-SSI $g_{\mathrm{m}}=$ $1.42 \pm 0.2, p<0.05$ when compared with post-SSI and post-SSI with DC current injection; $n=3$; data not shown). Some of these LTS interneurons were filled with biocytin $(n=32)$. SSI could be induced in 1 out of 1 CCK-positive cell (data not shown), in 16 out of 23 SST-positive interneurons (Fig. 1D) $\left(\Delta V_{\mathrm{m}}=-6.0 \pm\right.$ $0.65 \mathrm{mV}$ after SSI-inducing AP trains $p<0.001$ ), and in 4 out of 7 cells which were negative to both CCK and SST (data not shown). We have previously demonstrated that SSI is due to a persistent CB1 receptor-dependent activation of a GIRK conductance (Bacci et al., 2004). Accordingly, in 3 out of 5 SST + LTS 
cells, application of CB1R antagonist AM-251 (3 $\mu \mathrm{M})$ terminated the SSI-induced hyperpolarization (Fig. $1 H)\left(\Delta V_{\mathrm{m}}=-2.66 \pm\right.$ $2.18 \mathrm{mV} 10 \mathrm{~min}$ after AM-251 application; $p>0.05)$. These results indicate that SST + interneurons express a CB1-mediated SSI similar to CCK-containing cells.

We found that an activity-dependent long-lasting hyperpolarization in LTS interneurons required at least 100 spikes at $10 \mathrm{~Hz}$ $(p<0.01, n=5)$ and the amplitude of the hyperpolarization was progressively increased through further prolongation of the spike train (data not shown).

\section{Intracellular blockade of DAGL prevents SSI in neocortical LTS interneurons}

To test whether the endocannabinoid 2-AG was involved in LTScell SSI, we prevented its biosynthesis by including in the wholecell pipette either THL or O-3841, two inhibitors of DAGLs (Bisogno et al., 2003, 2006), the enzymes required to convert 1,2-diacylglycerol (1,2-DAG) into 2-AG. The two compounds are at least 160-fold selective for 2-AG over anandamide biosynthesis, and do not interact directly with $\mathrm{CB} 1$ receptors at the concentrations used to block DAGL (Bisogno et al., 2006). In the presence of either THL $(1 \mu \mathrm{M})$ or O-3841 $(3 \mu \mathrm{M})$, SSI-inducing stimuli failed to trigger significant long duration changes in either membrane potential or conductance in LTS interneurons (Figs. $2 C-F, 3$ ). Under vehicle control condition (intracellular DMSO 1 $\mu \mathrm{l} / \mathrm{ml})$ SSI-inducing action potential trains induced membrane potential hyperpolarizations of $6.8 \pm 0.1 \mathrm{mV}$ (Figs. $2 A, 3 A)(p<$ $0.001, n=11$; paired $t$ test). In contrast, no change in membrane potential was observed in the posttrain equivalent period with THL and O-3841 in the intracellular solution (Figs. 2C,E, 3A) (THL: $-1.0 \pm 1.3 \mathrm{mV}, n=7, p>0.5$; O-3841: $-1.5 \pm 1.7 \mathrm{mV}$ $n=9, p>0.5$ ). SSI-inducing stimuli elicited increases in normalized $g_{\mathrm{m}}$ (Fig. $3 B$ ) (ratio of membrane conductance pre- and post-SSI of $1.6 \pm 0.1 ; p<0.02$, paired $t$ test; $n=6$ ) comparable to those reported in previous experiments (Bacci et al., 2004). The increased conductance was blocked by intracellular THL (Fig. $3 B$ ) (normalized $g_{\mathrm{m}}$ following SSI-inducing stimuli was $1.1 \pm$ $0.04 ; p>0.05, n=8$ ) or by $\mathrm{O}-3841$ (normalized $g_{\mathrm{m}} 1.3 \pm 0.14$; $p>0.05, n=7)$. Normalized $g_{\mathrm{m}}$ after the trains was significantly higher in control than in O-3841 and THL $(p<0.03)$.

\section{PLC $\boldsymbol{\beta}$ blockade prevents SSI in LTS interneurons}

Diacylglycerols (DAGs) are DAGL substrates for 2-AG production (Piomelli, 2003; Di Marzo et al., 2005). A prominent pathway for DAG biosynthesis involves PLC $\beta$, which converts the phospholipid phosphatidylinositol into 1,2 diacylglycerol $(1,2$ DAG). This process can be triggered by rises of $\left[\mathrm{Ca}^{2+}\right]_{\mathrm{i}}$, such as those occurring during sustained electrical activity. PLC $\beta$ activity provides substrates for DAGL during activity-dependent 2-AG production (Piomelli, 2003; Bisogno et al., 2005). To test whether 2-AG produced by PLC activity was involved in SSI, we blocked PLC using U-73122 (5 $\mu \mathrm{M})$. Inclusion of the drug in the patch pipette (as in experiments involving THL or O-3841 depicted in Figs. 2, 3) was not feasible, because under these conditions (intracellular U-73122 perfusion) LTS interneurons were unstable and could not be recorded for longer than few minutes. Slices were therefore preincubated for at least 15 min with U-73122 in the extracellular solution and cells were then recorded in the continuous presence of the PLC blocker. Under these conditions, the aforementioned toxic effects were absent and recordings from LTS interneurons were stable. In the presence of U-73122, SSI was prevented in LTS interneurons (Fig. 4A). Overall, membrane potential measured $7 \mathrm{~min}$ after SSI-inducing trains was not
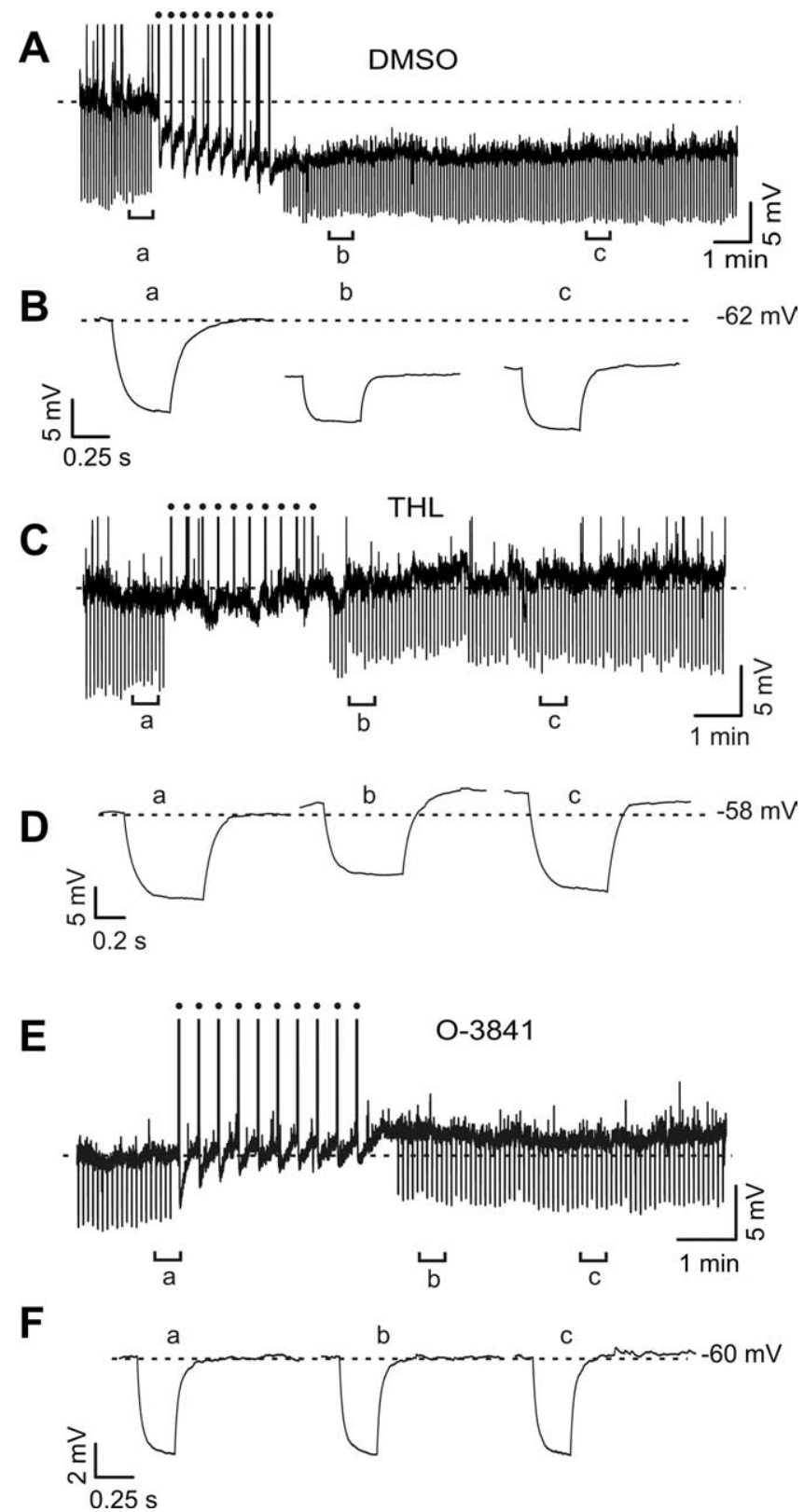

Figure 2. Two DAGL inhibitors prevent SSI in LTS interneurons. $A$, Continuous current-clamp recording of an LTS interneuron, intracellularly perfused with vehicle ( $1 \mu \mathrm{l} / \mathrm{ml}$ DMSO), showing the persistent hyperpolarization typical of SSI following 10 trains of 60 action potentials each at $50 \mathrm{~Hz}$ as indicated by the solid circles. Action potentials truncated for display purposes. $\boldsymbol{B}$, Voltage responses to negative current injections $(-20 \mathrm{pA})$ before $(\boldsymbol{a})$ and $1.5(\boldsymbol{b})$ and $10 \mathrm{~min}(\boldsymbol{c})$ after the spike trains in the cell of $\boldsymbol{A}$. Traces are average of 10 trials each. Note the marked reduction of the response to the same current injection indicating an increase of membrane conductance. C, Current-clamp recording of an LTS interneuron intracellularly perfused with the potent DAGL inhibitor tetrahydrolipstatin (THL, $1 \mu \mathrm{M}$ ). Note the absence of the hyperpolarization following the SSI-inducing paradigm identical to that used in Figure 1D. D, Voltage responses to negative current injections $(-20 \mathrm{pA})$ before $(\boldsymbol{a})$ and $1.5(\boldsymbol{b})$ and $10 \mathrm{~min}(\boldsymbol{c})$ after the spike trains in the cell of $C$. Traces are average of 10 trials each. Note that overall lack of reduction of the response to the same current injection at 10 min, despite a small change of membrane conductance immediately after the trains. $\boldsymbol{E}, \boldsymbol{F}$, Experiment similar to that of A-B, performed in a different LTS interneuron in the presence of the specific DAGL blocker 0-3841 (3 $\mu \mathrm{M})$. 0-3841 prevented the induction of SSI, as did THL.

significantly different from control pretrain periods $\left(\Delta V_{\mathrm{m}}=\right.$ $-1.8 \pm 1.7 \mathrm{mV}, p>0.2 ; n=5)$. Similarly, PLC blockade by U-73122 prevented membrane conductance changes normally associated with SSI (normalized $g_{\mathrm{m}}$ after SSI-inducing spike 

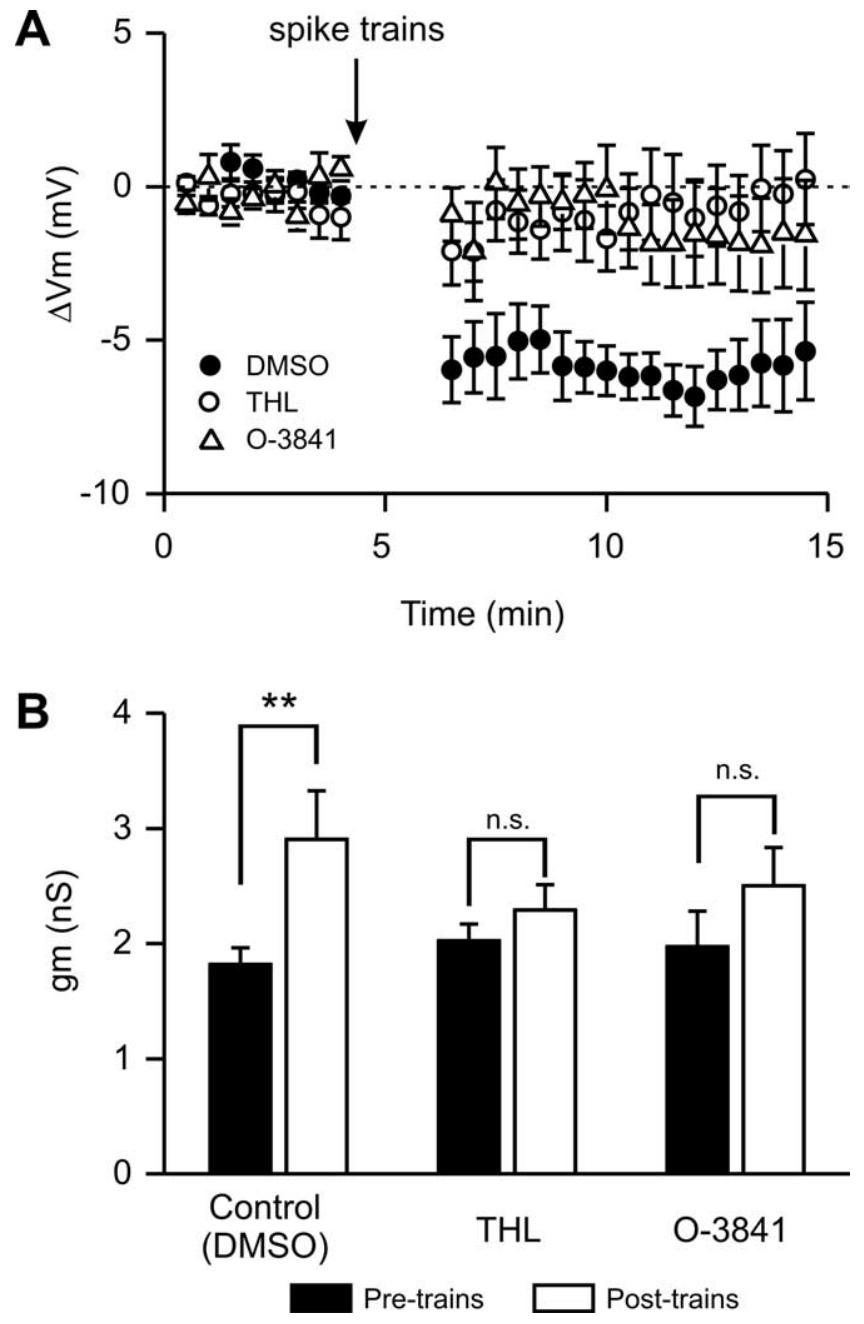

Figure 3. Population data of THL and 0-3841 effects on LTS cell SSI. $\boldsymbol{A}$, Composite plot of subtracted membrane potential $\left(\Delta V_{m}\right.$, i.e., the difference in $V_{m}$ before and after $S S I$ inducing stimuli) in control conditions with $1 \mu \mathrm{l} / \mathrm{ml}$ DMSO in the whole cell pipette (solid circles), and in the presence of THL (open circles) or 0-3841 (open triangles). SSI-inducing spike trains indicated by the arrow. Membrane potential measurements were omitted during the spike trains. $B$, Population data showing membrane conductance $\left(g_{\mathrm{m}}\right)$ in control (DMSO), or with THL or 0-3841 in the whole-cell pipette before (black columns) and 5 min after (white columns) the spike trains. The increase in $g_{m}$ evoked by AP trains in control solution (left graph, ${ }^{* *} p<0.01$ ) was blocked by both DAGL inhibitors (middle and right graphs, n.s. = no significant difference; $p>0.05 ; n=8$ and 7 for $0-3841$ and THL respectively).

trains was $1.0 \pm 0.01 ; p>0.05, n=5)$. We repeated the same experiment in the presence of U-73343 $(5 \mu \mathrm{M})$, an inactive analog of U-73122. In the presence of U-73343, LTS-cell SSI was similar to that found under control conditions (Fig. $4 B$ ). Overall, membrane potential hyperpolarization was $-10.9 \pm 2.5 \mathrm{mV}$ after SSIinducing trains $(n=5 ; p<0.01)$. Moreover, normalized $g_{\mathrm{m}}$ was $1.4 \pm 0.02$ after action potential trains $(p<0.05 ; n=5)$, similar to the SSI induced increase in $g_{\mathrm{m}}$ in control conditions (Fig. $3 B$ ). It is possible that DAGL and PLC inhibitors prevented SSI by blocking signaling events downstream from CB1R activation. We therefore applied 2-AG with a local perfusion pipette in the continuous presence of extracellular U-73122 and intracellular THL. Exogenous application of 2-AG resulted in a consistent hyperpolarization of $V_{\mathrm{m}}\left(\Delta V_{\mathrm{m}}=-7.8 \pm 0.1, p<0.05, n=5\right)$ (supplemental Fig. S3, available at www.jneurosci.org as supplemental material), ruling out the possibility that DAGL and PLC blockers affected processes downstream from $\mathrm{CB} 1$ receptor activation.

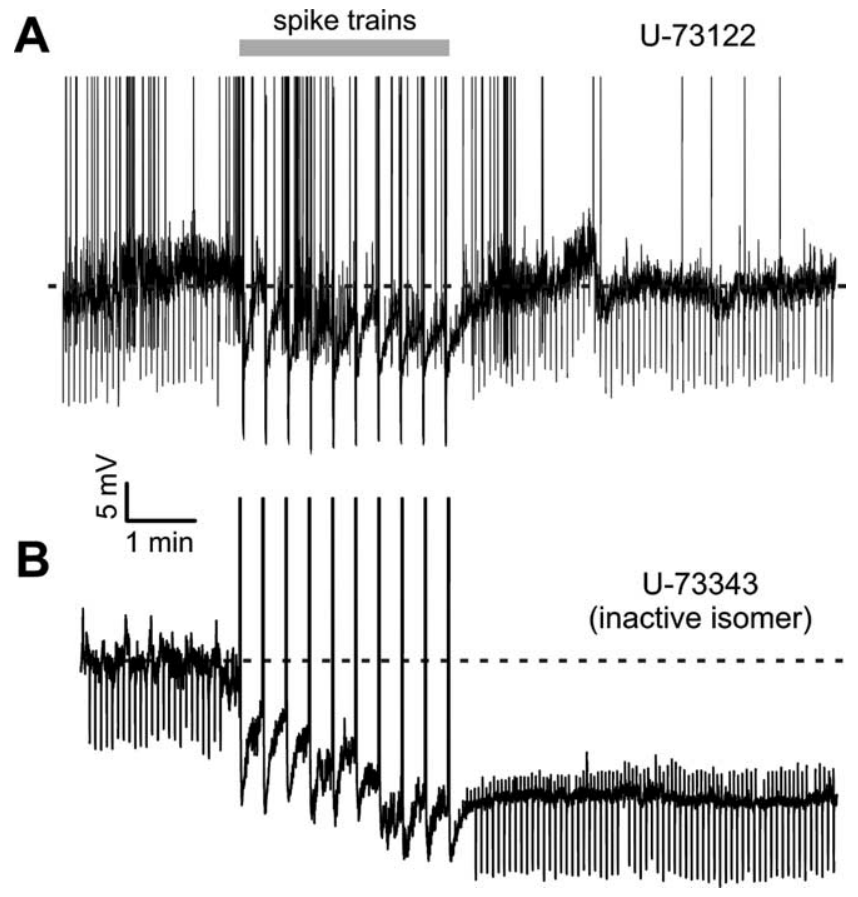

Figure 4. PLC blockade prevents LTS cell SSI. A, Current-clamp recording of an LTS interneuron in the constant presence of the PLC blocker U-73122 $(5 \mu \mathrm{M})$ in the extracellular solution. 10 SSI-inducing trains at $50 \mathrm{~Hz}$ every $20 \mathrm{~s}$ (gray bar) did not affect membrane potential. $\boldsymbol{B}$, Currentclamp recording obtained from another LTS cell in the continuous presence of U-73343 $(5 \mu \mathrm{M})$, an inactive isomer of U-73122. The same SSI-inducing protocol resulted in prolonged hyperpolarization.

\section{mGlu5-dependent activation of PLC $\beta$ induces a}

hyperpolarization in LTS interneurons, mediated by 2 -AG

Activation of group I mGluRs results in PLC $\beta$ stimulation associated with endocannabinoid synthesis and modulation of synaptic transmission (Varma et al., 2001; Brown et al., 2003; Freund et al., 2003; Piomelli, 2003; Jung et al., 2005, 2007; Maejima et al., 2005; Chevaleyre et al., 2006). In particular, activation of the mGlu5 subtype of group I mGluRs results in selective 2-AG formation, with no significant change in anandamide production (Jung et al., 2005, 2007). We then reasoned that an mGlu5dependent activation of PLC $\beta$ should produce $2-A G$ and thus mimic SSI in LTS interneurons. In the presence of the $\mathrm{Na}^{+}$channel blocker TTX $(0.5 \mu \mathrm{M})$, local perfusion of the selective mGlu5 agonist CHPG (1 mM) resulted in a prominent depolarization of LTS cells, consistent with the known activation of a cationic channel by group I mGluRs (Guérineau et al., 1995; Tempia et al., 1998; Kim et al., 2003). Upon CHPG washout, membrane potential persistently hyperpolarized, mimicking SSI (Fig. $5 \mathrm{~A}, \mathrm{~B})\left(V_{\mathrm{m}}\right.$ $=-60.0 \pm 2.2 \mathrm{vs}-66.4 \pm 2.0 \mathrm{mV}$, predrug vs $5 \mathrm{~min}$ after $\mathrm{CHPG}$ washout; $p<0.01 ; n=5$; Wilcoxon signed-rank test). Membrane conductance greatly increased during CHPG application (Fig. $5 A$ ), consistent with the opening of membrane ion channels with a depolarized equilibrium potential. During CHPG washout, membrane conductance transiently returned to predrug values before increasing during the persistent membrane potential hyperpolarization (Fig. $5 B$, right) $\left(g_{\mathrm{m}}=2.1 \pm 0.1 \mathrm{nS}\right.$ pre-CHPG vs $2.6 \pm 0.2 \mathrm{nS} 5 \mathrm{~min}$ after CHPG washout; $p<0.02 ; n=5$ ). To test whether the long-lasting hyperpolarization following CHPG local perfusion was similar to SSI and thus endocannabinoidmediated, we repeated the same experiments in the presence of the CB1 antagonist AM251 $(2 \mu \mathrm{M})$. When AM251 was present, CHPG application produced the prominent depolarization but 

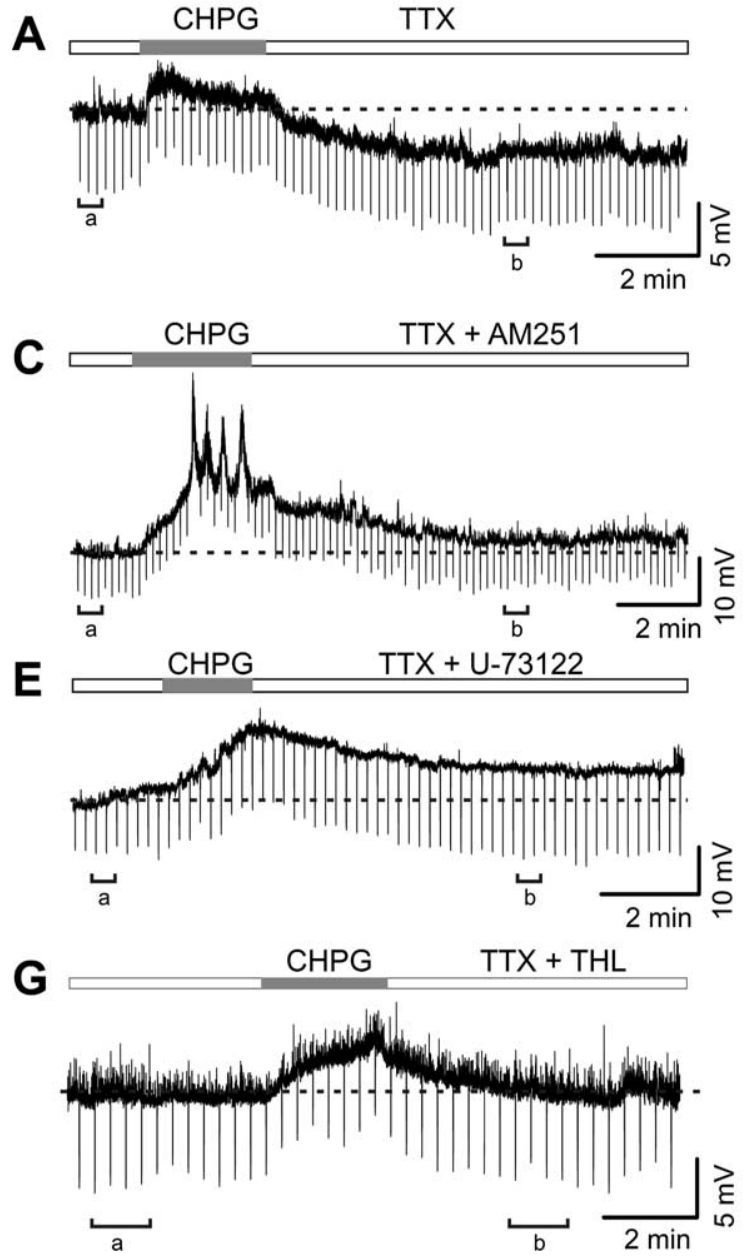

Figure 5. mGlu5 activation produces a persistent CB1-dependent hyperpolarization that mimics SSI in LTS interneurons. $\boldsymbol{A}_{\boldsymbol{t}}$ Current-clamp recording of an LTS interneuron in the constant presence of the $\mathrm{Na}^{+}$channel blocker tetrodotoxin (TTX, $0.5 \mu \mathrm{M}$; white horizontal bar). Local perfusion of the mGlu5 specific agonist CHPG (1 mM, gray horizontal bar) produced a depolarization followed by a persistent hyperpolarization when the drug was washed out. Horizontal dashed line: resting $V_{\mathrm{m}}(-61 \mathrm{mV})$. $\boldsymbol{B}$, Summary plot of changes of membrane potential (left) and conductance (right) at the time points $(\boldsymbol{a}, \boldsymbol{b})$ indicated in $\boldsymbol{A}$. $\boldsymbol{C}$, Current-clamp recording of another LTS interneuron in the constant presence of TTX and the CB1 antagonist AM251 (2 $\mu \mathrm{M})$. mGlu5 activation (gray bar) depolarized the cell with no apparent hyperpolarization following CHPG washout. Horizontal dashed line: resting $V_{m}(-62 \mathrm{mV})$. D, Summary plot of changes of membrane potential and conductance at the time points $(\boldsymbol{a}, \boldsymbol{b})$ indicated in $\boldsymbol{C}$. $\boldsymbol{E}-\boldsymbol{H}$, Similar experiment as in A-C in the continuous presence of the PLC blocker U-73122 (E-F) or the DAGL inhibitor THL(GH). ${ }^{* * *} p<0.001 ;{ }^{*} p<0.05 ;$ ns: not significantly different, Wilcoxon signed-rank test.

not the long-lasting hyperpolarization (Fig. 5C,D), indicating that CB1Rs were involved in the CHPG-dependent late hyperpolarization. Overall, membrane potential did not significantly hyperpolarize in LTS interneurons in the presence of AM251 $\left(V_{\mathrm{m}}=\right.$ $-62.0 \pm 2.9$ predrug vs $-61.4 \pm 3.6 \mathrm{mV} .5 \mathrm{~min}$ after $\mathrm{CHPG}$ washout; $p>0.1, n=5$ ). Moreover, the late membrane conductance increase occurring during CHPG washout was prevented by AM251 application (Fig. $5 D$, right) $\left(g_{\mathrm{m}}=2.0 \pm 0.3\right.$ pre-CHPG vs $2.1 \pm 0.3 \mathrm{nS} 5 \mathrm{~min}$ after CHPG washout; $p>0.1, n=5$ ).

The involvement of PLC $\beta$ in this CHPG-mediated effect was confirmed, as the late hyperpolarization was prevented by U-73122 $\left(V_{\mathrm{m}}\right.$ and $g_{\mathrm{m}}$ were $-58.1 \pm 2.4 \mathrm{mV}$ and $1.8 \pm 0.3 \mathrm{nS}$, respectively pre-CHPG and $-57.8 \pm 2.4 \mathrm{mV}$ and $2.2 \pm 0.6 \mathrm{nS}, 5 \mathrm{~min}$ after CHPG washout; $p>0.1$ in both cases, $n=5$ ) (Fig. $5 E, F)$. Moreover, the late hyperpolarization was also blocked by the DAGL inhibitor THL $\left(V_{\mathrm{m}}\right.$ and $g_{\mathrm{m}}$ were $=-56.9 \pm 2.1$ and $2.0 \pm 0.4 \mathrm{nS}$, respectively preCHPG and $-58.7 \pm 2.5 \mathrm{mV}$ and $2.3 \pm 0.4 \mathrm{nS} 5 \mathrm{~min}$ after $\mathrm{CHPG}$ washout; $p>0.1$ in both cases, $n=6$ ) (Fig. $5 G, H$ ). These data indicate that $\mathrm{mGlu} 5$ activation in LTS interneurons produced a PLC $\beta$ - and DAGLdependent synthesis of 2-AG, resulting in a hyperpolarization that mimicked SSI.

\section{Discussion}

Slow self-inhibition (SSI) of LTS cortical interneurons is an endocannabinoiddependent persistent and prominent change of somatodendritic excitability. We have previously shown that LTS interneurons in layer $\mathrm{V}$ of the neocortex include CCK-positive cells (Bacci et al., 2004), consistent with earlier reports (Kawaguchi and Kubota, 1997, 1998). This agrees with the known expression of CB1Rs in CCK-containing interneurons in both neocortex and hippocampus (Freund et al., 2003). However, LTS firing behavior is also a prominent feature of somatostatin (SST)-containing Martinotti cells (Cauli et al., 1997; Kawaguchi and Kondo, 2002; Goldberg et al., 2004; Ma et al., 2006). We show that the majority of LTS interneurons recorded here do indeed express SST. Recently, immunohistochemical analysis (Katona et al., 2006) and single-cell RT-PCR (Hill et al., 2007) revealed that CB1Rs are expressed by glutamatergic neurons and other subtypes of GABAergic cells. In particular, CB1 mRNA has been found in a significant percentage of SST-positive interneurons (Hill et al., 2007), in agreement with previous evidence indicating that a significant percentage of calbindin D28 $8_{\mathrm{K}}$-positive cortical interneurons-thus likely coexpressing SST (Cauli et al., 1997, 2000; Kawaguchi and Kubota, 1997; Hill et al., 2007) - express CB1 receptors (Marsicano and Lutz, 1999). In line with this evidence, we showed that activity-dependent slow selfinhibition occurs in the vast majority of LTS interneurons that we recorded (78\%), including SST-positive cells, identified with post hoc immunocytochemistry. Accordingly, neocortical neurons showing an LTS firing behavior responded to exogenous applications of 2-AG with a prominent hyperpolarization (Bacci et al., 2004) (supplemental Fig. 3, available at www.jneurosci.org as supplemental material). These data indicate that in deep cortical layers CB1Rs are functionally expressed by a large percentage of SST-positive and virtually all CCK-expressing LTS interneurons.

Anandamide and 2-AG are the best characterized endogenous cannabinoids and, in particular, 2-AG is the most abundant endocannabinoid in the CNS, with a higher efficacy at CB1Rs than anandamide (Freund et al., 2003; Piomelli, 2003; Di Marzo et al., 2005). Here we show that the persistent hyperpolarization following repetitive firing of neocortical LTScells is prevented by blocking the biosynthesis of 2-AG. Production of 2-AG was specifically impaired by blocking two crucial enzymes involved in its biosynthesis. We first blocked DAGL using two different drugs. We used tetrahydrolipstatin 
(THL or orlistat), which is a potent blocker of DAGL and other lipases (Lee et al., 1995; Bisogno et al., 2003, 2006; Hashimotodani et al., 2008) with little or no activity on the enzyme catalyzing anandamide biosynthesis (Lee et al., 1995; Bisogno et al., 2003, 2006). In addition, we used a newly synthesized compound, O-3841, which was shown to be less potent than THL but much more specific for $s n-1-D A G$ lipase (Bisogno et al., 2006). The experimental approach of including these two drugs in the whole-cell intracellular solution excludes the possibility that their effects of blocking SSI in LTS cells could be attributed to indirect actions of these molecules on other cells embedded in the network. Moreover, intracellular delivery of these DAGL inhibitors clearly indicates that 2-AG is produced by the same LTS neuron that underwent repetitive cycles of activity, confirming that SSI is mediated by an autocrine endocannabinoid action. Control experiments, performed in the presence of equivalent amounts of the drug solvent DMSO, rule out the possibility that SSI blockade could be induced by the drug vehicle perfused intracellularly.

The production of 2-AG in the somatodendritic compartment of LTS interneurons correlates with the expression of DAGL in dendrites of neurons in postembryonic developmental stages, as opposed to its axonal distribution during embryonic development (Bisogno et al., 2003; Yoshida et al., 2006). On the other hand, the 2-AG degrading enzyme monoacylglycerol lipase (MAGL) is localized mainly in presynaptic terminals, as are CB1 receptors (Dinh et al., 2002; Gulyas et al., 2004). This might in part explain the long-lasting nature of SSI, which is induced and maintained in the somatodendritic compartments lacking the enzyme responsible for breaking down 2-AG. This endocannabinoid would thus remain at higher concentrations and exert a prolonged interaction with $\mathrm{CB} 1$ receptors, as suggested by experiments in which late application of CB1 antagonist AM251 only partially reversed the hyperpolarization and membrane conductance changes induced by SSI stimuli (Bacci et al., 2004) (Fig. 1). On the other hand, elevated MAGL expression in presynaptic terminals might underlie the short-term dynamics of DSI (Alger, 2002), as suggested by experiments in which DSI duration was increased by blockade of MAGL (Makara et al., 2005; Szabo et al., 2006). Eventually, also in the absence of MAGL, 2-AG might be inactivated either via incorporation into phospholipids or by fatty acid amide hydrolase (FAAH) (Di Marzo et al., 1998), which is predominantly a postsynaptic enzyme (Gulyas et al., 2004), as opposed to presynaptic localization of MAGL. Furthermore, two other lipases, Abh6 and Abh12, have been recently identified in the brain and shown to recognize 2-AG as a substrate (Blankman et al., 2007), although their anatomical and cellular distribution in the brain is not known.

DAGL-dependent production of 2-AG relies on the availability of diacylglycerols, which can be produced by PLC $\beta$ activity. There is compelling evidence that $2-\mathrm{AG}$ production in forebrain neurons depends more strongly on PLC $\beta$ and DAGL than other biosynthetic pathways (Stella et al., 1997; Freund et al., 2003; Piomelli, 2003; Jung et al., 2007), and 2-AG has been suggested to be the retrograde messenger involved in shortand long-term synaptic modulation (Melis et al., 2004; Makara et al., 2005; Safo and Regehr, 2005; Chevaleyre et al., 2006; Szabo et al., 2006; Hashimotodani et al., 2007, 2008). However, PLC $\beta$ involvement in endocannabinoid-mediated retrograde synaptic signaling is still unclear. Both pharmacological and genetic analyses strongly suggest PLC-dependent
2-AG production triggered by mGluR and/or muscarinic ACh receptor activation in short- and long-term synaptic plasticity (Kim et al., 2002; Hashimotodani et al., 2005; Maejima et al., 2005; Chevaleyre et al., 2006). In contrast, PLC $\beta$ involvement in briefer depolarization- and DAGL-dependent DSI/DSE is still controversial (Chevaleyre and Castillo, 2003; Edwards et al., 2006; Szabo et al., 2006; Hashimotodani et al., 2008).

We found that LTS-cell SSI depends on PLC $\beta$-like activity. This was supported by two lines of evidence. First, SSI was prevented in the presence of U-73122, which is a known PLC $\beta$ inhibitor, widely used in biochemical and physiological studies to prevent PLC $\beta$ activity. This drug was recently reported to have undesired unspecific effects (Hashimotodani et al., 2008). However, the presence of robust SSIs induced in LTS interneurons in the presence of U-73122's inactive analog U-73343 suggests that SSI blockade by U-73122 is likely due to its known effects on PLC, even though we cannot completely exclude unspecific effects by the drug. However, LTS cells consistently hyperpolarized when locally perfused with 2-AG in the presence of U-73122 (as well as THL), indicating that the PLC blocker does not affect CB1-sensitive $\mathrm{K}^{+}$channels (Sickmann et al., 2008).

Second, group I mGluR-dependent PLC $\beta$ activation produced a CB1-dependent hyperpolarization mimicking SSI in LTS cells. This mGlu5-dependent hyperpolarization resulted from PLC $\beta$ activation, as it was prevented by U-73122. Group I mGluR-dependent PLC $\beta$ activation results in endocannabinoid synthesis (Maejima et al., 2001; Varma et al., 2001; Alger, 2002; Safo and Regehr, 2005; Chevaleyre et al., 2006), and, in particular, the mGlu5 subtype of group I mGluRs was shown to selectively induce 2-AG synthesis in rat corticostriatal and hippocampal slice cultures (Jung et al., 2005). Accordingly, the persistent hyperpolarization and conductance increase triggered in LTS interneurons by selective mGlu5 activation and prevented by the $\mathrm{CB} 1$ antagonist AM251, was mediated by 2-AG, as it was prevented when DAGL activity was pharmacologically impaired. It will be interesting to investigate whether glutamate released during sustained network activities can activate mGluRs and thus elicit the endocannabinoiddependent SSI in LTS interneurons. PLC $\beta$ activation by direct $\mathrm{Ca}^{2+}$ increases, such as those triggered by SSI-inducing action potential trains is still controversial (Chevaleyre and Castillo, 2003; Edwards et al., 2006; Szabo et al., 2006; Hashimotodani et al., 2008). PLC activation requires a certain level of intracellular $\mathrm{Ca}^{2+}$ (Rebecchi and Pentyala, 2000), and interestingly, isoforms of PLC that are highly sensitive to $\mathrm{Ca}^{2+}$ and are expressed in cortex and hippocampus have recently been identified (PLC $\eta 1$ and PLC $\eta 2$ ) (Hwang et al., 2005; Nakahara et al., 2005). During cortical network activity, a synergistic action between mGluR activation and action potential firing could exist, with a resulting modulation of LTS-cell SSI, similar to that shown in cerebellar DSE (Brenowitz and Regehr, 2005).

Altogether, our results suggest that during repetitive action potential firing, LTS interneurons activate PLC $\beta$, which provides DAGL with its natural substrates for $2-A G$ production. This can in turn activate CB1 receptors in the same cells and trigger long-lasting self-inhibition through a persistent hyperpolarization. In our control experiments LTS interneurons consistently generated SSI (supplemental Fig. 1, available at www.jneurosci.org as supplemental material) that was prevented by DAGL and PLC blockers, although. SSI could not be elicited in all SST-positive LTS cells. 
It is possible that anandamide is also involved in SSI, but we could not directly test its role in SSI induction, because to date there is no selective pharmacological tool available to impair its biosynthesis. However, even if produced by repetitive firing in LTS cells, anandamide might not be efficient in inducing persistent SSI, as the enzyme specific for its degradation, the fatty acid amide hydrolase (FAAH) is expressed in somata and dendrites of cortical neurons (Romero et al., 2002; Egertová et al., 2003; Piomelli, 2003). This suggests that even if anandamide were produced by repetitive firing, it would be quickly degraded. Moreover, recent evidence indicates that anandamide can, under certain conditions, downregulate 2-AG biosynthesis (Maccarrone et al., 2008), arguing against a possible synergistic effect of the two endocannabinoids. Finally, if anandamide were involved in LTS-cell SSI, a residual hyperpolarization should have been present when 2-AG biosynthesis was blocked by PLC and DAGL inhibitors, at least immediately after SSI-inducing trains.

In the neocortex and hippocampus, interneurons are important players in cortical circuit activity. Some interneurons such as basket cells are responsible for induction and maintenance of various cortical oscillations, by providing feedback inhibition onto glutamatergic pyramidal cells (Freund, 2003; Whittington and Traub, 2003; Buzsáki et al., 2004). In contrast, other GABAergic interneurons target pyramidal cell dendrites and might be thus responsible for filtering excitation onto pyramidal neurons (Pouille and Scanziani, 2001; Xiang et al., 2002; Pouille and Scanziani, 2004). Neocortical LTS interneurons belong to this latter class of cells (Xiang et al., 2002; Bacci et al., 2005) and their self-induced inhibition by 2-AG might provide a persistent tuning of information processing along the dendritic axis of pyramidal cells.

\section{References}

Alger BE (2002) Retrograde signaling in the regulation of synaptic transmission: focus on endocannabinoids. Prog Neurobiol 68:247-286.

Bacci A, Huguenard JR, Prince DA (2003a) Functional autaptic neurotransmission in fast-spiking interneurons: a novel form of feedback inhibition in the neocortex. J Neurosci 23:859-866.

Bacci A, Rudolph U, Huguenard JR, Prince DA (2003b) Major differences in inhibitory synaptic transmission onto two neocortical interneuron subclasses. J Neurosci 23:9664-9674.

Bacci A, Huguenard JR, Prince DA (2004) Long-lasting self-inhibition of neocortical interneurons mediated by endocannabinoids. Nature 431:312-316.

Bacci A, Huguenard JR, Prince DA (2005) Modulation of neocortical interneurons: extrinsic influences and exercises in self-control. Trends Neurosci 28:602-610.

Bisogno T, Sepe N, Melck D, Maurelli S, De Petrocellis L, Di Marzo V (1997) Biosynthesis, release and degradation of the novel endogenous cannabimimetic metabolite 2-arachidonoylglycerol in mouse neuroblastoma cells. Biochem J 322:671-677.

Bisogno T, Melck D, De Petrocellis L, Di Marzo V (1999) Phosphatidic acid as the biosynthetic precursor of the endocannabinoid 2-arachidonoylglycerol in intact mouse neuroblastoma cells stimulated with ionomycin. J Neurochem 72:2113-2119.

Bisogno T, Howell F, Williams G, Minassi A, Cascio MG, Ligresti A, Matias I, Schiano-Moriello A, Paul P, Williams EJ, Gangadharan U, Hobbs C, Di Marzo V, Doherty P (2003) Cloning of the first sn 1-DAG lipases points to the spatial and temporal regulation of endocannabinoid signaling in the brain. J Cell Biol 163:463-468.

Bisogno T, Ligresti A, Di Marzo V (2005) The endocannabinoid signalling system: biochemical aspects. Pharmacol Biochem Behav 81:224-238.

Bisogno T, Cascio MG, Saha B, Mahadevan A, Urbani P, Minassi A, Appendino G, Saturnino C, Martin B, Razdan R, Di Marzo V (2006) Development of the first potent and specific inhibitors of endocannabinoid biosynthesis. Biochim Biophys Acta 1761:205-212.

Blankman JL, Simon GM, Cravatt BF (2007) A comprehensive profile of brain enzymes that hydrolyze the endocannabinoid 2-arachidonoylglycerol. Chem Biol 14:1347-1356.

Bodor AL, Katona I, Nyíri G, Mackie K, Ledent C, Hájos N, Freund TF (2005) Endocannabinoid signaling in rat somatosensory cortex: laminar differences and involvement of specific interneuron types. J Neurosci 25:6845-6856.

Brenowitz SD, Regehr WG (2005) Associative short-term synaptic plasticity mediated by endocannabinoids. Neuron 45:419-431.

Brown SP, Brenowitz SD, Regehr WG (2003) Brief presynaptic bursts evoke synapse-specific retrograde inhibition mediated by endogenous cannabinoids. Nat Neurosci 6:1048-1057.

Buzsáki G, Geisler C, Henze DA, Wang XJ (2004) Interneuron diversity series: circuit complexity and axon wiring economy of cortical interneurons. Trends Neurosci 27:186-193.

Cadas H, di Tomaso E, Piomelli D (1997) Occurrence and biosynthesis of endogenous cannabinoid precursor, $N$-arachidonoyl phosphatidylethanolamine, in rat brain. J Neurosci 17:1226-1242.

Cadas H, Gaillet S, Beltramo M, Venance L, Piomelli D (1996) Biosynthesis of an endogenous cannabinoid precursor in neurons and its control by calcium and cAMP. J Neurosci 16:3934-3942.

Cauli B, Audinat E, Lambolez B, Angulo MC, Ropert N, Tsuzuki K, Hestrin S, Rossier J (1997) Molecular and physiological diversity of cortical nonpyramidal cells. J Neurosci 17:3894-3906.

Cauli B, Porter JT, Tsuzuki K, Lambolez B, Rossier J, Quenet B, Audinat E (2000) Classification of fusiform neocortical interneurons based on unsupervised clustering. Proc Natl Acad Sci U S A 97:6144-6149.

Chevaleyre V, Castillo PE (2003) Heterosynaptic LTD of hippocampal GABAergic synapses: a novel role of endocannabinoids in regulating excitability. Neuron 38:461-472.

Chevaleyre V, Takahashi KA, Castillo PE (2006) Endocannabinoidmediated synaptic plasticity in the CNS. Annu Rev Neurosci 29:37-76.

Deadwyler SA, Hampson RE, Mu J, Whyte A, Childers S (1995) Cannabinoids modulate voltage sensitive potassium A-current in hippocampal neurons via a cAMP-dependent process. J Pharmacol Exp Ther 273:734-743.

Devane WA, Hanus L, Breuer A, Pertwee RG, Stevenson LA, Griffin G, Gibson D, Mandelbaum A, Etinger A, Mechoulam R (1992) Isolation and structure of a brain constituent that binds to the cannabinoid receptor. Science 258:1946-1949.

Di Marzo V, Matias I (2005) Endocannabinoid control of food intake and energy balance. Nat Neurosci 8:585-589.

Di Marzo V, Fontana A, Cadas H, Schinelli S, Cimino G, Schwartz JC, Piomelli D (1994) Formation and inactivation of endogenous cannabinoid anandamide in central neurons. Nature 372:686-691.

Di Marzo V, Bisogno T, Sugiura T, Melck D, De Petrocellis L (1998) The novel endogenous cannabinoid 2-arachidonoylglycerol is inactivated by neuronal- and basophil-like cells: connections with anandamide. Biochem J 331:15-19.

Di Marzo V, De Petrocellis L, Bisogno T (2005) The biosynthesis, fate and pharmacological properties of endocannabinoids. Handb Exp Pharmacol 147-185.

Dinh TP, Carpenter D, Leslie FM, Freund TF, Katona I, Sensi SL, Kathuria S, Piomelli D (2002) Brain monoglyceride lipase participating in endocannabinoid inactivation. Proc Natl Acad Sci U S A 99:10819-10824.

Edwards DA, Kim J, Alger BE (2006) Multiple mechanisms of endocannabinoid response initiation in hippocampus. J Neurophysiol 95:67-75.

Egertová M, Cravatt BF, Elphick MR (2003) Comparative analysis of fatty acid amide hydrolase and $\mathrm{cb}(1)$ cannabinoid receptor expression in the mouse brain: evidence of a widespread role for fatty acid amide hydrolase in regulation of endocannabinoid signaling. Neuroscience 119:481-496.

Freund TF (2003) Interneuron diversity series: rhythm and mood in perisomatic inhibition. Trends Neurosci 26:489-495.

Freund TF, Katona I, Piomelli D (2003) Role of endogenous cannabinoids in synaptic signaling. Physiol Rev 83:1017-1066.

Goldberg JH, Lacefield CO, Yuste R (2004) Global dendritic calcium spikes in mouse layer 5 low threshold spiking interneurones: implications for control of pyramidal cell bursting. J Physiol 558:465-478.

Guérineau NC, Bossu JL, Gähwiler BH, Gerber U (1995) Activation of a nonselective cationic conductance by metabotropic glutamatergic and muscarinic agonists in CA3 pyramidal neurons of the rat hippocampus. J Neurosci 15:4395-4407.

Gulyas AI, Cravatt BF, Bracey MH, Dinh TP, Piomelli D, Boscia F, Freund TF (2004) Segregation of two endocannabinoid-hydrolyzing enzymes into 
pre- and postsynaptic compartments in the rat hippocampus, cerebellum and amygdala. Eur J Neurosci 20:441-458.

Hájos N, Katona I, Naiem SS, Mackie K, Ledent C, Mody I, Freund TF (2000) Cannabinoids inhibit hippocampal GABAergic transmission and network oscillations. Eur J Neurosci 12:3239-3249.

Hashimotodani Y, Ohno-Shosaku T, Tsubokawa H, Ogata H, Emoto K, Maejima T, Araishi K, Shin HS, Kano M (2005) Phospholipase Cbeta serves as a coincidence detector through its $\mathrm{Ca} 2+$ dependency for triggering retrograde endocannabinoid signal. Neuron 45:257-268.

Hashimotodani Y, Ohno-Shosaku T, Kano M (2007) Presynaptic monoacylglycerol lipase activity determines basal endocannabinoid tone and terminates retrograde endocannabinoid signaling in the hippocampus. J Neurosci 27:1211-1219.

Hashimotodani Y, Ohno-Shosaku T, Maejima T, Fukami K, Kano M (2008) Pharmacological evidence for the involvement of diacylglycerol lipase in depolarization-induced endocanabinoid release. Neuropharmacology 54:58-67.

Hill EL, Gallopin T, Férézou I, Cauli B, Rossier J, Schweitzer P, Lambolez B (2007) Functional CB1 receptors are broadly expressed in neocortical GABAergic and glutamatergic neurons. J Neurophysiol 97:2580-2589.

Hwang JI, Oh YS, Shin KJ, Kim H, Ryu SH, Suh PG (2005) Molecular cloning and characterization of a novel phospholipase C, PLC-eta. Biochem J 389:181-186.

Iversen L (2003) Cannabis and the brain. Brain 126:1252-1270.

Jung KM, Mangieri R, Stapleton C, Kim J, Fegley D, Wallace M, Mackie K, Piomelli D (2005) Stimulation of endocannabinoid formation in brain slice cultures through activation of group I metabotropic glutamate receptors. Mol Pharmacol 68:1196-1202.

Jung KM, Astarita G, Zhu C, Wallace M, Mackie K, Piomelli D (2007) A key role for diacylglycerol lipase-\{alpha\} in metabotropic glutamate receptordependent endocannabinoid mobilization. Mol Pharmacol 72:612-621.

Katona I, Sperlágh B, Sík A, Käfalvi A, Vizi ES, Mackie K, Freund TF (1999) Presynaptically located CB1 cannabinoid receptors regulate GABA release from axon terminals of specific hippocampal interneurons. J Neurosci 19:4544-4558.

Katona I, Urbán GM, Wallace M, Ledent C, Jung KM, Piomelli D, Mackie K, Freund TF (2006) Molecular composition of the endocannabinoid system at glutamatergic synapses. J Neurosci 26:5628-5637.

Kawaguchi Y, Kondo S (2002) Parvalbumin, somatostatin and cholecystokinin as chemical markers for specific GABAergic interneuron types in the rat frontal cortex. J Neurocytol 31:277-287.

Kawaguchi Y, Kubota Y (1997) GABAergic cell subtypes and their synaptic connections in rat frontal cortex. Cereb Cortex 7:476-486.

Kawaguchi Y, Kubota Y (1998) Neurochemical features and synaptic connections of large physiologically-identified GABAergic cells in the rat frontal cortex. Neuroscience 85:677-701.

Kim J, Isokawa M, Ledent C, Alger BE (2002) Activation of muscarinic acetylcholine receptors enhances the release of endogenous cannabinoids in the hippocampus. J Neurosci 22:10182-10191.

Kim SJ, Kim YS, Yuan JP, Petralia RS, Worley PF, Linden DJ (2003) Activation of the TRPC1 cation channel by metabotropic glutamate receptor mGluR1. Nature 426:285-291.

Kreitzer AC, Regehr WG (2001) Retrograde inhibition of presynaptic calcium influx by endogenous cannabinoids at excitatory synapses onto Purkinje cells. Neuron 29:717-727.

Lee MW, Kraemer FB, Severson DL (1995) Characterization of a partially purified diacylglycerol lipase from bovine aorta. Biochim Biophys Acta 1254:311-318.

Liu J, Wang L, Harvey-White J, Huang BX, Kim HY, Luquet S, Palmiter RD, Krystal G, Rai R, Mahadevan A, Razdan RK, Kunos G (2008) Multiple pathways involved in the biosynthesis of anandamide. Neuropharmacology $54: 1-7$.

Ma Y, Hu H, Berrebi AS, Mathers PH, Agmon A (2006) Distinct subtypes of somatostatin-containing neocortical interneurons revealed in transgenic mice. J Neurosci 26:5069-5082.

Maccarrone M, Rossi S, Bari M, De Chiara V, Fezza F, Musella A, Gasperi V, Prosperetti C, Bernardi G, Finazzi-Agrò A, Cravatt BF, Centonze D (2008) Anandamide inhibits metabolism and physiological actions of 2-arachidonoylglycerol in the striatum. Nat Neurosci 11:152-159.

Mackie K, Hille B (1992) Cannabinoids inhibit N-type calcium channels in neuroblastoma-glioma cells. Proc Natl Acad Sci U S A 89:3825-3829.

Mackie K, Lai Y, Westenbroek R, Mitchell R (1995) Cannabinoids activate an inwardly rectifying potassium conductance and inhibit Q-type calcium currents in AtT20 cells transfected with rat brain cannabinoid receptor. J Neurosci 15:6552-6561.

Maejima T, Hashimoto K, Yoshida T, Aiba A, Kano M (2001) Presynaptic inhibition caused by retrograde signal from metabotropic glutamate to cannabinoid receptors. Neuron 31:463-475.

Maejima T, Oka S, Hashimotodani Y, Ohno-Shosaku T, Aiba A, Wu D, Waku K, Sugiura T, Kano M (2005) Synaptically driven endocannabinoid release requires $\mathrm{Ca}^{2+}$-assisted metabotropic glutamate receptor subtype 1 to phospholipase $C \beta 4$ signaling cascade in the cerebellum. J Neurosci 25:6826-6835.

Makara JK, Mor M, Fegley D, Szabó SI, Kathuria S, Astarita G, Duranti A, Tontini A, Tarzia G, Rivara S, Freund TF, Piomelli D (2005) Selective inhibition of 2-AG hydrolysis enhances endocannabinoid signaling in hippocampus. Nat Neurosci 8:1139-1141.

Marsicano G, Lutz B (1999) Expression of the cannabinoid receptor CB1 in distinct neuronal subpopulations in the adult mouse forebrain. Eur J Neurosci 11:4213-4225.

Mechoulam R, Hanus L, Martin BR (1994) Search for endogenous ligands of the cannabinoid receptor. Biochem Pharmacol 48:1537-1544.

Mechoulam R, Ben-Shabat S, Hanus L, Ligumsky M, Kaminski NE, Schatz AR, Gopher A, Almog S, Martin BR, Compton DR (1995) Identification of an endogenous 2-monoglyceride, present in canine gut, that binds to cannabinoid receptors. Biochem Pharmacol 50:83-90.

Melis M, Perra S, Muntoni AL, Pillolla G, Lutz B, Marsicano G, Di Marzo V, Gessa GL, Pistis M (2004) Prefrontal cortex stimulation induces 2-arachidonoyl-glycerol-mediated suppression of excitation in dopamine neurons. J Neurosci 24:10707-10715.

Nakahara M, Shimozawa M, Nakamura Y, Irino Y, Morita M, Kudo Y, Fukami K (2005) A novel phospholipase C, PLC(eta)2, is a neuronspecific isozyme. J Biol Chem 280:29128-29134.

Ohno-Shosaku T, Maejima T, Kano M (2001) Endogenous cannabinoids mediate retrograde signals from depolarized postsynaptic neurons to presynaptic terminals. Neuron 29:729-738.

Piomelli D (2003) The molecular logic of endocannabinoid signalling. Nat Rev Neurosci 4:873-884.

Pouille F, Scanziani M (2001) Enforcement of temporal fidelity in pyramidal cells by somatic feed-forward inhibition. Science 293:1159-1163.

Pouille F, Scanziani M (2004) Routing of spike series by dynamic circuits in the hippocampus. Nature 429:717-723.

Rebecchi MJ, Pentyala SN (2000) Structure, function, and control of phosphoinositide-specific phospholipase C. Physiol Rev 80:1291-1335.

Romero J, Hillard CJ, Calero M, Rábano A (2002) Fatty acid amide hydrolase localization in the human central nervous system: an immunohistochemical study. Brain Res Mol Brain Res 100:85-93.

Safo PK, Regehr WG (2005) Endocannabinoids control the induction of cerebellar LTD. Neuron 48:647-659.

Sasaki T, Chang MC (1997) N-arachidonylethanolamine (anandamide) formation from $\mathrm{N}$-arachidonylphosphatidylethanolamine in rat brain membranes. Life Sci 61:1803-1810.

Sickmann T, Klose A, Huth T, Alzheimer C (2008) Unexpected suppression of neuronal $\mathrm{G}$ protein-activated, inwardly rectifying $\mathrm{K}^{+}$current by common phospholipase C inhibitor. Neurosci Lett 436:102-106.

Simon GM, Cravatt BF (2008) Anandamide biosynthesis catalyzed by the phosphodiesterase GDE1 and detection of glycerophospho-N-acyl ethanolamine precursors in mouse brain. J Biol Chem 283:9341-9349.

Stella N, Piomelli D (2001) Receptor-dependent formation of endogenous cannabinoids in cortical neurons. Eur J Pharmacol 425:189-196.

Stella N, Schweitzer P, Piomelli D (1997) A second endogenous cannabinoid that modulates long-term potentiation. Nature 388:773-778.

Sugiura T, Kondo S, Sukagawa A, Nakane S, Shinoda A, Itoh K, Yamashita A, Waku K (1995) 2-Arachidonoylglycerol: a possible endogenous cannabinoid receptor ligand in brain. Biochem Biophys Res Commun 215:89-97.

Sugiura T, Kondo S, Sukagawa A, Tonegawa T, Nakane S, Yamashita A, Ishima Y, Waku K (1996a) Transacylase-mediated and phosphodiesterase-mediated synthesis of $\mathrm{N}$-arachidonoylethanolamine, an endogenous cannabinoidreceptor ligand, in rat brain microsomes. Comparison with synthesis from free arachidonic acid and ethanolamine. Eur J Biochem 240:53-62.

Sugiura T, Kondo S, Sukagawa A, Tonegawa T, Nakane S, Yamashita A, Waku K (1996b) Enzymatic synthesis of anandamide, an endogenous cannabinoid receptor ligand, through $\mathrm{N}$-acylphosphatidylethanolamine path- 
way in testis: involvement of $\mathrm{Ca}(2+)$-dependent transacylase and phosphodiesterase activities. Biochem Biophys Res Commun 218:113-117.

Szabo B, Urbanski MJ, Bisogno T, Di Marzo V, Mendiguren A, Baer WU, Freiman I (2006) Depolarization-induced retrograde synaptic inhibition in the mouse cerebellar cortex is mediated by 2 -arachidonoylglycerol. J Physiol 577:263-280.

Tempia F, Miniaci MC, Anchisi D, Strata P (1998) Postsynaptic current mediated by metabotropic glutamate receptors in cerebellar Purkinje cells. J Neurophysiol 80:520-528.

Uematsu M, Hirai Y, Karube F, Ebihara S, Kato M, Abe K, Obata K, Yoshida S, Hirabayashi M, Yanagawa Y, Kawaguchi Y (2008) Quantitative chemical composition of cortical GABAergic neurons revealed in transgenic venus-expressing rats. Cereb Cortex 18:315-330.

Varma N, Carlson GC, Ledent C, Alger BE (2001) Metabotropic glutamate receptors drive the endocannabinoid system in hippocampus. J Neurosci 21:RC188(1-5).

Whittington MA, Traub RD (2003) Interneuron diversity series: inhibitory interneurons and network oscillations in vitro. Trends Neurosci 26:676-682.

Wilson RI, Kunos G, Nicoll RA (2001) Presynaptic specificity of endocannabinoid signaling in the hippocampus. Neuron 31:453-462.

Xiang Z, Huguenard JR, Prince DA (2002) Synaptic inhibition of pyramidal cells evoked by different interneuronal subtypes in layer $\mathrm{v}$ of rat visual cortex. J Neurophysiol 88:740-750.

Yoshida T, Fukaya M, Uchigashima M, Miura E, Kamiya H, Kano M, Watanabe M (2006) Localization of diacylglycerol lipase-alpha around postsynaptic spine suggests close proximity between production site of an endocannabinoid, 2-arachidonoyl-glycerol, and presynaptic cannabinoid CB1 receptor. J Neurosci 26:4740-4751 . 